\title{
СУЧАСНЕ/АКТУАЛЬНЕ МИСТЕЦТВО В ХУДОЖНІЙ КРИТИЦІ КИЕВА ПОЧАТКУ ХХІ СТОЛІТТЯ
}

\begin{abstract}
У статті на основі вивчення публікацій періодичних видань столиці України розкрито принципи розрізнення понять актуального та сучасного мистецтва художньою критикою Києва та причини, які зумовили розмитість дефініцій зазначених термінів в украӥнському мистецтвознавчому і культурологічному дискурсі початку ХХІ століття.

Зроблені висновки про те, щзо розмаїтий ландшафт мистецьького життя нашої держави початку XXI століття, бажання позначити і структурувати повноту виявів, впливів і зіткнень мистецьких процесів сьогодення спонукає київських критиків формувати власну класифікаџію різних векторів його розвитку. На шпальтах періодики, крім словосполучень «сучасне мистецттво», «актуальне мистецтвво», з 'являються й інші, зокрема «сучасне модерне мистецтво» (у певних випадках як прагнення виділити новаторські пошуки в живописі), «контемпорарне (новітнє) мистецтво», «сучасне актуальне мистецтво» (як спроба маркування в річищі мистецтва, яке нині існує в художній практиці). Влучність вживання вказаних термінів залежить від контексту застосування, зумовленого часом, а тому не може мати однозначного тлумачення.

У художній критиці початку ХХІ століття иі поняття підпорядковані дифузї, оскільки автори під час розгляду художніх явищ, певного мистещьького проекту, творчості художників прагнуть маркувати поле дискурсу цими термінами без їх додаткового тлумачення. В сучасному мистецькому просторі така рефлексія здебільшого спрямована на глядача як потениійного споживача, тому актуалізується постать мистия, менше актуалізуються смисли, які він репрезентує у свойх творах. Такий підхід здебільшого нівелює сутність понять «сучасне» й «актуальне», ніж сприяє формуванню чіткого термінологічного апарату для вказаного виду науково-творчої діяльності.

У статті наголошується на необхідності вироблення науковою думкою Украӥни термінологічного апарату, зрозумілого науковцям інших країн, тобто синхронізованого із загальною мистеитвознавчою та культурологічною термінологією, щзо продиктовано глобалізаційними процесами.
\end{abstract}

Ключові слова: сучасне мистецтво, актуальне мистецтво, contemporary art, художня критика.

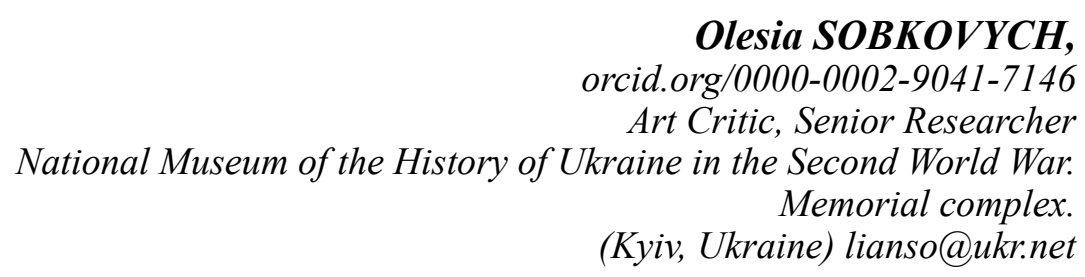

\section{CONTEMPORARY/CURRENT (ACTUAL) IN THE KYIV ART CRITICISM IN XXI CENTURY}

The article, based on the study of the periodicals in the capital of Ukraine, reveals the distinguishing principles between current and contemporary art by art critics of Kyiv and the reasons that led to the blurring of these terms definitions in Ukrainian art-exploring and cultural discourse of the early XXI century.

It is concluded that the diverse landscape of our country's artistic life at the beginning of the XXI century, the desire to define and structure the fullness of manifestations, influences and collisions of today artistic processes, encourages Kyiv critics to form their own classification of various vectors of its development. Accordingly, in the columns of the periodical, in addition to the phrases "contemporary art", "currently emerging art", there are others, including "contemporary modern art" (in some cases as a desire to highlight the innovative search in painting), "contemporary (latest) art", or "contemporary emerging art" (as an attempt to mark in the art stream that the adequate to current time art practices exist today), etc. Hence, the precision of these terms usage depends on the context of use, due to time and therefore cannot have the unambiguous interpretation. 
In art criticism of the early XXI century these concepts are subject to diffusion, as the authors in considering artistic phenomena, a particular art project, the work of artists, seek to mark the field of discourse with these terms, without their further interpretation. In the contemporary art space, such a reflection is mainly focused on the viewer as a potential consumer, so the figure of the artist is actualized, the meanings that he represents in his works are less actualized. This approach, for the most part, eliminates the essence of the "contemporary" and "relevant" concepts than contributes to the formation of the clear terminological instruments for this type of scientific and creative activity.

The article emphasizes the necessity to develop the terminological instruments by scientific thought of Ukraine, clear to scientists of other countries, namely synchronized with the general art and cultural terminology, which is determined by globalization processes.

Key words: modern art, currently emerging (relevant) art, contemporary art, art criticism.

Постановка проблеми. Актуальність дослідження питання співвідношення понять «сучасне» й «актуальне» мистецтво зумовлена розмитістю їх дефініцій в українському мистецтвознавчому i культурологічному дискурсі, що відображають як тексти періодики, присвячені розгляду мистецьких явищ художнього життя початку XXI століття, так і публікації окресленого часу, в яких київські мистецтвознавці і критики роблять спроби осмислити наявну термінологічну невизначеність.

Аналіз досліджень. Питанню співвідношення понять «сучасне / актуальне мистецтво» в мистецькому просторі України початку XXI століття приділяє увагу Г. Вишеславський, В. Бурлака, О. Голубець, Л. Смирна, В. Хаматов, А. Пучков, Т. Злобіна, Д. Скринник-Миська, О. Балашова. Публікації цих авторів розкривають авторське розуміння вказаних дефініцій, що залишає простір для узагальнень і більш детального вивчення досліджуваного питання.

Мета статті - виявлення й осмислення принципів розрізнення понять актуального й сучасного мистецтва художньою критикою Києва.

Виклад основного матеріалу. Розрізненість трактування зазначених термінів пов'язана 3 низкою причин. Серед них - відсутність одностайності поглядів серед міжнародних інституцій, науковців і митців у визначенні часових меж $\mathrm{i}$ сутності "contemporary art", до яких часто апелюють київські оглядачі художнього життя при поясненні понять «сучасне» й «актуальне» мистецтво. Це спонукає розглянути основні підходи закордонних дослідників і теоретиків щодо того, що $\epsilon$ сучасним мистецтвом (contemporary art), або що саме робить мистецьке явище / подію сучасним.

Перший із них грунтується на виявленні тих кардинальних змін (їх хронологіi) в культурному та мистецькому полі, які вказують на появу нових його характеристик і стратегій, потребують термінологічного визначення.

Нині серед західних інституцій / науковців щодо поглядів на хронологію появи сучасного мистецтва існує твердження про те, що події Другої світової війни істотно вплинули на сві- домість художників і стали відліком неповернення до мистецтва у тому вигляді, в якому воно було, яким сприймалося до цієї події. Тому відлік contemporary art доцільно розпочинати після закінчення Другої світової війни. Цієї позиції дотримується Інститут сучасного мистецтва у Лондоні (The Institute of Contemporary Art in London). Також існує думка, згідно 3 якою відправною точкою (початком) сучасного мистецтва варто вважати кінець XX - початок XXI століття.

Проте, найбільш розповсюдженими є судження, які пов'язують його поступ із кардинальними змінами у сфері мистецтва 60-70-х рр. XX ст. Найчастіше під ними розуміють період появи понять «постмодернізм», «постмодерн», окреслення закінчення легко класифікованих художніх рухів і розмаїття підходів у створенні мистецьких творів.

Так, Національна галерея міжнародного модерністського й сучасного мистецтва Тейт Модерн (Tate Modern) орієнтується на 1970-ті роки як кінцеву межу виникнення contemporary art (Contemporary art. Art Term). Британський мистецтвознавець і критик М. Арчер поступ contemporary art пов'язує із 1960-ми роками. Історикиня мистецтва К. Річман-Абду говорить про закінчення епохи модернізму (кінець $1960-\mathrm{x}$ - поч. $1970-х$ років) як відлік сучасного мистецтва, яке розпочалося на основі поп-арту (вперше створений художниками Е. Уорхолом і Р. Ліхтенштейном), якому властива зацікавленість у змалюванні масової культури, переосмислення комерційних продуктів як доступного мистецтва (Richman-Abdou, 2019).

У цьому контексті варто навести роздуми американського філософа та критика А. Данто. У своїй публікації «Світ Мистецтва» критик, аналізуючи мистецький процес, говорить про творчість Е. Уорхола для унаочнення настання нової віхи в мистецькому світі. Це період, в якому об’єкт, який важко ідентифікувати мистецьким, набуває такого значення (мистецького твору) внаслідок його визнання і прийняття мистецьким світом, що забезпечує теорія мистецтва (розуміння / позиціонування його таким спеціалістами в царині історії та теорії мистецтва). 
Міркування А. Данто позначають істотні зміни поступу художнього процесу, в якому серед розмаїття мистецьких інтенцій лише фахівці здатні розпізнати варті уваги твори (Danto, 1964: 582). Це спонукає звернутися до інституційної теорії мистецтва (як іiі сформулював американський філософ Дж. Дікі), згідно якої відмінність твору мистецтва від його антиподу визначається контекстом його функціонування, системою фахових інституцій, з яких складається арт-простір / світ. Зазначені особливості, на думку більшості науковців, вирізняють contemporary art від мистецтва попереднього часу.

Існує й інший підхід у розгляді сутності сучасного мистецтва. Він грунтується на розумінні цього явища як певної мистецької діяльності, за допомогою якої відбувається формування сучасності. Таким чином при розгляді поняття сучасного мистецтва наявним $\epsilon$ зміщення акценту 3 мистецтва на сучасність, не тільки сучасність визначає мистецтво, а й мистецтво - сучасність.

Серед інших причин термінологічної плутанини варто зазначити особливості перекладу терміну "contemporary art" в українському мистецькому середовищі, який тлумачать і як сучасне мистецтво, і як актуальне мистецтво (зустрічається і поняття новітне мистецтво, рідше - модерне). Тож смислове навантаження усіх трьох понять стає зрозумілим лише з контексту їх застосування, а відмінність або тотожність часто визначається відповідно до авторського бачення ситуації, принципів, від яких відштовхуються дослідники при визначенні зазначених понять. На цю особливість вказує мистецтвознавець Г. Вишеславський, зазначаючи, що «точність вживання зазначених термінів позначає кут зору на предмет, про який пише мистецтвознавець» (Вишеславський, 2015: 87).

«Точкою відліку» одночасного застосування понять сучасне / актуальне мистецтво в українському арт-середовищі (так само як і перші спроби їх виведення) є 90-ті роки XX століття. Їх співіснування було пов'язано 3 необхідністю термінологічно маркувати та розмежувати мистецькі інтенції, які відповідали естетиці постмодернізму, модернізму, явища, що співвідносилися з розумінням мистецтва, сформованим за радянських часів.

На початку XXI століття терміни «актуальне» i «сучасне» мистецтво найчастіше вживають як синоніми. Більшість критиків у їх трактуванні відштовхуються від розуміння того, що сучасне / актуальне мистецтво $є$ відкритою системою, яка характеризується розмаїттям мистецьких явищ певного часу, це «мистецтво сьогоднішнього дня, яке (за браком часу) ще не можна визначити як певний стиль чи напрям» (Вишеславський, 2015: 87). Однак помилково вважати, що йдеться лише про темпоральний показник виникнення й експонування мистецтва, адже такий підхід апелює до розмитих / рухливих хронологічних меж, не вказує на сталий часовий відрізок, тобто нівелює можливість точного визначення кола творчих інтенцій / явищ, які мають статус сучасного, і тих, які вже його втратили.

Не є вичерпним і розуміння сучасного мистецтва як створеного художником-сучасником, оскільки воно апелює до широкого кола мистецьких виявів / явищ, поєднує мистецькі інтенції, які несуть кардинально нове змістовне наповнення (естетичне, філософське, тематичне) і мають інноваційний характер, з тими, де вони відсутні. Це порушує питання необхідності маркування мистецтва певного часу будь-якими додатковими означеннями на кшталт «сучасне / актуальне». Визнаючи цей факт, більшість критиків, відштовхуючись від основної прикметної риси сучасного мистецтва - «відсутності єдиного організуючого принципу, ідеології чи «-ізму» (Contemporary Art in Context, 2016), вводять додаткові уточнюючі координати, що сприяе конкретизації розуміння поняття «сучасне / актуальне мистецтво».

Одним із визначальних у цьому контексті $\epsilon$ критерій актуальності твору локальному і світовому мистецькому просторам. На думку більшості оглядачів художнього життя, сучасне мистецтво набуває свого статусу за умови відповідності міжнародному поступу, спроможності на належному рівні підтримувати із ним комунікацію. На необхідність відповідати критеріям певного міжнародного художнього процесу, бути частиною глобального культурного діалогу як необхідну умову / показник належності до сучасного / актуального мистецтва вказує мистецтвознавиця В. Бурлака, Л. Смирна, В. Хаматов, А. Пучков, медіа-активіст і публіцист О. Радинський. Останній зазначає: «... сучасне мистецтво привілеює рівнобіжність темпорального виміру, належність до єдиного хронологічного контексту. Не відповідати цим вимогам означає не належати до сфери «сучасного мистецтва», яке не може бути актуальним на місцевому рівні й неактуальним назовні» (Радинський, 2010).

Цього принципу дотримується й художник, арт-критик і куратор Єжи Онух. В українських реаліях поняття «сучасне мистецтво» як еквівалент світового "contemporary art" мистець, серед інших, означує діяльність київської групи Р.Е.П., харківського гурту «SOSка» та мисткині Алевтіни Кахідзе. Такий вибір є очевидним з огляду на те, що творчість вказаних мистецьких об'єднань 
(акція «Р.Е.П.» “We will P.E.П. уоu”, проект групи «SOSка» «Мрійники», «Вони на вулиці», «Бартер») є прикладом мистецтва, яке має соціальнокритичне спрямування, де важливим $€$ не естетичні питання, а заглиблення в соціально-психологічні, соціально-культурні контексти, що відповідає світовій художній практиці залучення мистецтва у суспільно значущі теми, розуміння сучасного мистецтва як способу надання соціальних і культурних коментарів, що виявляє його важливість для суспільства і забезпечує його визнання.

Зауважимо, що принцип універсальності сучасного мистецтва не нівелює можливості звернення художників до локальних традицій. Передбачається, що «новітнє мистецтво поєднує основу місцевих традицій і глобальні світові тенденції» (Смирная, 2016: 164). Зазвичай йдеться про вільне застосування класики і традиції шляхом цитування та перекроювання, гри 3 елементами та кодами будь-яких культур, зокрема і традиційних, яким $\epsilon$ і народне автентичне мистецтво. Як наслідок, творчість українських мистців, позначена поєднанням національного забарвлення 3 ідеями, образами та засобами художньої виразності, вписаними у постмодерністську культурну парадигму, оглядачами художнього життя означується як сучасне/актуальне мистецтво (contemporary art) У цьому контексті розглядається діяльність О. Тістола, О. Рідного, П. Старуха.

Статус сучасного мистецтва досягається i завдяки зіткненню різного розуміння, відмінних концепцій мистецтва (наприклад, традиційної східної і європейської). Слушні міркування 3 цього приводу висловлює німецький художник і теоретик медіа-мистецтва П. Вайбель. Розглядаючи питання доречності презентації так званого національного мистецтва у контексті contemporary art в аспекті ідеї глобалізації (універсальності), мистець зазначає, що «ідея глобалізації полягає не в тому, щоб надавати перевагу одній культурі над іншою, як це було у модернізмі. Глобалізація пропонує переглянути співвідношення та контексти локального й космополітичного, національного та всесвітнього, регіонального й інтернаціонального» (Вайбель, 2010: 37).

В цьому аспекті важливими $є$ міркування мистецтвознавця Г. Вишеславського, який підіймає питання ступеню універсальності contemporary art (його проблематики), що здебільшого орієнтується на європейську та американську культурну ситуацію щодо інших культур і необхідності постійного пошуку актуальності для зв'язку із сучасністю. Зауважимо, що підняте науковцем питання актуалізує постконцептуальне мисте- цтво, яке передбачає поєднання / співставлення в одному творі мистецтва різних (протилежних) концептів мистецтва (різного його тлумачення), що і визначає його цінність і сучасність.

Загалом розгляд художньою критикою Києва понять «сучасне» та «актуальне» мистецтво варто розкрити, проаналізувавши організацію побудови творів, типові ознаки, які позначаються наведеними вище термінами, розуміння ролі художника в мистецькому процесі й інше.

Викладений вище матеріал спонукає більш детально розглянути одну з визначальних рис мистецтва - його кореляцію із сучасністю, що виявляється в актуалізації проблематики поточного часу. Для більшості оглядачів художнього життя це означає звернення до наявних політичних дошкульних питань, інтервенцію у сферу соціальних відносин. Інші акцентують увагу на проблемах, породжених новітніми технологіями для гуманітарного світу і людини, екологічних питаннях, проблемах ідентифікації, пошуку людиною свого місця у світі. Зауважимо, що така проблематика характерна і для мистецтва, яке трактується як «актуальне мистецтво». Так, до актуального мистецтва відносять проекти учасниці групи «Р.Е.П.» Л. Хоменко, які підіймають актуальні проблеми сучасного суспільства і можуть слугувати прикладами їх інтелектуального дослідження (проєкт «Дивокрай», серія "Superstars").

В обох випадках міркування критиків суголосні роздумам щодо сутності сучасного мистецтва філософа, мистецтвознавця i куратора Б. Гройса, який акцентував увагу на тому, що «сучасне мистецтво заслуговує свого імені, якщо воно демонструє сучасність, а не лише якщо зроблене і виставлене у теперішній момент» (Гройс, 2012: 78). При цьому слушне зауваження вносить мистецтвознавиця Н. Маценко, наголошуючи на тому, що до кола актуальних проблем і завдань, 3 якими працює сучасне мистецтво, варто віднести «і злободенне, яке стосується лише поточного моменту, ті питання, які не втрачають своєї актуальності протягом тисячоліть, потребуючи відповіді» (Маценко, 2018).

Під поняттям «сучасне мистецтво» критики розуміють мистецтво, яке прагне проникнути у повсякденне життя. У цьому відчувається вплив міркувань одного з провідних теоретиків постмодернізму, німецького художника Й. Бойса, який проголосив мистецтвом «усе, що лежить під сонцем». Йдеться про стирання / розмивання кордонів між мистецтвом і життям. Оскільки останнє мислиться як певний процес, важливим стає саме він, а не матеріальне втілення твору чи кінце- 
вий результат. Тому розширення меж мистецтва шляхом звернення до енвайроментів, хепенінгів і перформансів, які передбачають комунікацію, налагодження діалогу 3 глядачем, спонукають до переосмислення і руйнування суспільних міфів та пошуку нових смислів, трактують прикметну рису сучасного мистецтва: «Мистецтвом виступають не самі об'єкти, а художній жест, яким художник «за замовчуванням» позначає зв'язок життя і мистецтва» (Скрипник-Миська, 2019: 277). Як бачимо, під поняттям «сучасне мистецтво» критики розглядають public art i piзновиди акціонізму, художнє документування, вияви так званої дематеріалізації мистецтва (термін введено американською арт-критикинею Л. Ліпард), що передбачає заміщення об'єкту мистецтва описом чи текстом. Таким чином істотна частина сучасного мистецтва мислиться як враження глядача про художній жест.

Конкретизації розуміння художньою критикою Києва поняття «сучасне мистецтво» сприяє й розгляд суджень щодо типових ознак та організації побудови твору, яка може виражатися цим терміном. Істотною рисою такого мистецтва, на думку критиків, є його експериментальний характер (замість наслідування традицій чи відтворення усталених шаблонів), що виявляється у дослідженні певних ідей, цінностей, стереотипів, контекстів і подальшої гри 3 ними; відборі та комбінуванні / нашаруванні культурних текстів і кодів; апробації залучення у сферу мистецтва не художніх методів і новітніх технологій, зокрема медіа. Досить точно окреслює цю особливість мистецтвознавиця М. Шейніна: «Сучасне мистецтво харчується і підживлюється старим - не формою і кольором, основами композиційної побудови, а ретельно пережовує і перетравлює духовний зміст - відчуття / враження, спосіб мислення якусь хворобливість свідомості / усвідомлення себе і світу, світу в собі» (Шейнина, 2000: 55).

Сутнісною особливістю сучасного мистецтва, на якій наголошують критики, $є$ фокусування уваги на смислових значеннях і контекстах, які несе або до яких апелює мистецький твір, його здатності актуалізувати наявні дошкульні питання шляхом конструювання потужного семантичного простору навколо неї за допомогою добору відповідних засобів і методів (зокрема, комунікативних форм висловлювання).

Поняття «сучасного мистецтва» критики асоціюють із медійністю та інтерактивністю, які визначають його доступність і масовість, складають основу для художньої фотографії, відеоарту й інших видів медіамистецтва. Синтезування різних практик, ведення активного критичного діалогу 3 наукою, політикою і економікою визначило інтегральну та комунікаційну природу мистецтва, яка вказує на діалог між автором, твором і глядачем.

Зазначені особливості характеру сучасного мистецтва зумовлюють і зміну статусу художника й глядача. На початку XXI століття критики згідно постмодерної парадигми сприймають художника сучасного мистецтва як режисера, який не винаходить (як це було в період модернізму), а комбінує існуючі значення (створює гіпертекст). Тобто творити означає досліджувати, а не виробляти кінцевий продукт. Глядач за таких умов сприймається як співавтор чи дійова особа твору. Тому до кола сучасного мистецтва долучають фестивалі, бієнале, проекти, в яких дотримано зазначених ролей (міжнародний фестиваль "Burning Man", що виключає відсторонену позицію глядачів, передбачаючи, що у загальному фестивальному дійстві певною мірою мають бути залучені всі). О. Авраменко зазначає: «Репрезентація сучасного «актуального» мистецтва відбувається багатоаспектно, «спілкування» 3 глядачем і провокація останнього на відгук. Головним вважають факт досягнення цієї реакції, виникнення феномену так званої інтерактивності» (Авраменко, 2006: 231).

Активним співучасником реципієнта робить не тільки його безпосередня залученість до певного мистецького жесту (участь у перформансах, хепенінгах та інтерактивних заходах / дійствах), а й множинність / варіативність глядацьких інтерпретацій твору сучасного мистецтва, який є відкритою системою. Таким чином, «Сучасне мистецтво, вийшовши за межі класичного мистецтва, поєднало в єдине ціле творця і глядача, витвір і результат, фабрику і сцену» (Смирная, 2016: 163).

Зауважимо, що експериментально-пошуковий характер мистецтва поточної доби, його інтерактивність, соціальна ангажованість, акцентування уваги на такі (колись маргінальні) практики як медіа, стріт-арт, цифрові технології частина критиків розглядає (у довільних комбінаціях) як визначальні риси актуального мистецтва. У цьому випадку здебільшого йдеться про дублювання одного терміну іншим, зумовленим особливостями перекладу українською мовою англомовного прототипу "contemporary art" - «актуальне мистецтво» замість «сучасне мистецтво» (О. Авраменко, О. Сидор-Гібелинда, Т. Злобіна, О. Балашова, К. Тейлор). Подібна ситуація в українських реаліях породжує існування словосполучення «сучасне актуальне мистецтво» як прагнення означити сегмент актуальних практик у сучас- 
ному мистецтві. Останнє при цьому вказує на поточний час створення мистецтва, $є$ суто хронологічним показником.

Якщо говорити про пункти, які визначають розбіжність понять сучасне / актуальне мистецтво, то варто звернути увагу на питання комерційності / некомерційності творів мистецтва, наявність провокації / епатажу як необхідної умови стратегії презентації, фокусування на чуттєвому чи раціональному характері сприйняття. Так чи інакше йдеться про те, що критики та мистецтвознавці сучасним / актуальним називають мистецтво, яке відповідає парадигмі постмодерну, про що пише i мистецтвознавець О. Сидор-Гібелінда, зазначаючи, що «contemporary art - синонім актуального, тобто експериментально-пошукового мистецтва наприкінці XX - на початку XXI століття. За наших умов - ситуативний синонім постмодерну» (Сидор-Гібелінда, 2008: 291). Варто уточнити, що часові рамки цього терміну позначають не час виникнення contemporary art в українській мистецькій ситуації, а окреслюють часові межі дотичності автора визначення до зазначеного мистецтва (він $є$ сучасником цього періоду), мають суб'єктивний складник.

Словосполучення «актуальне мистецтво» на початку XXI століття, окрім експериментального, набуває й іншого відтінку: його використовують для означення творів, які мають успіх у ринковій сфері. На це вказує Т. Злобіна, зазначаючи, що «слово «актуальний» як модний, трендовий, в руслі останніх тенденцій активно використовується у споживчих індустріях. Таким чином актуальне стає не-актуальним - перестає вдовільняти соціальний запит на експеримент і продукування альтернативного знання, втрачає громадянську значущість і перетворюється на індустрію 3 виробництва статусних художніх товарів» (Злобіна, 2010).

Варто зазначити, що доречність вживання терміну «актуальне мистецтво» як синоніму “contemporary art" викликає сумніви 3 огляду на його незрозумілість в європейському і американському мистецькому контексті («актуальне мистецтво» часто перекладають як “Actual Art", що є калькою), де поняттям Actual Art (термін увів критик А. Франкенштейн) означується жанр мистецтва, який передбачає залучення природи до процесу завершення мистецького твору, що значно звужує зміст поняття, закладений київськими критиками. Слушні зауваження щодо влучності застосування цього поняття висловлює i М. Сідлін, акцентуючи увагу на тому, що «інший можливий переклад англійського слова Actual - «достеменний». «Актуальне мистецтво» слідує за модерністським розумінням сучасного мистецтва як «автентичного» і суперечить постмодерністській парадигмі (Сідлін, 1999: 67).

Свої нюанси щодо вживання має і словосполучення «сучасне мистецтво». Так, у статті авторської групи Л. Смирної, В. Хаматова та А. Пучкова термін «сучасне мистецтво» пропонується застосовувати для характеристики мистецтва 1960-х - 1980-х років, натомість мистецтво зламу XX - XXI століття отримує значення «контемпорарного (новітнього, актуального) мистецтва». Подекуди воно застосовується для позначення мистецьких інтенцій, не пов'язаних із глобальним contemporary art.

Висновки. Дослідження розбіжностей у розумінні київською художньою критикою понять «сучасне / актуальне мистецтво» дає можливість дійти висновку, що розмаїтий ландшафт мистецького життя початку XXI століття, бажання означити і структурувати повноту виявів, впливів і зіткнень мистецьких процесів сьогодення спонукає київських критиків формувати власну класифікацію різних векторів його розвитку. На шпальтах періодики, крім словосполучень «сучасне мистецтво», «актуальне мистецтво», 3'являються й інші, зокрема «сучасне модерне мистецтво» (у певних випадках як прагнення виділити новаторські пошуки в живописі), «контемпорарне (новітнє) мистецтво», «сучасне актуальне мистецтва». Тому влучність вживання цих термінів залежить від контексту застосування, зумовленого часом, i не може мати однозначного тлумачення.

У художній критиці початку XXI століття ці поняття підпорядковані дифузії, оскільки автори при розгляді художніх явищ, певного мистецького проекту, творчості художників прагнуть маркувати поле дискурсу цими термінами без їх додаткового тлумачення. У сучасному мистецькому просторі така рефлексія здебільшого спрямована на глядача як потенційного споживача, тому актуалізується постать мистця, менше актуалізуються смисли, які він репрезентує у своїх творах. Такий підхід здебільшого нівелює сутність понять «сучасне» й «актуальне», ніж сприяє формуванню чіткого термінологічного апарату для означеного виду науково-творчої діяльності. Варто зазначити, що глобалізаційні процеси спонукають наукову думку України до вироблення термінологічного апарату, зрозумілого науковцям інших країн, тобто синхронізованого із загальною мистецтвознавчою та культурологічною термінологією. 


\section{СПИСОК ВИКОРИСТАНИХ ДЖЕРЕЛ}

1. Авраменко О. Зміни парадигми функціонування образотворчого мистецтва в Україні 1950-х - 2005-го років. Нариси з історії образотворчого мистецтвва України ХХ ст. К. : Інтертехнологія, 2006. Кн. 2. С. $193-240$.

2. Вайбель П. Ми живемо за часів, для яких характерна криза компетентності. Art Ukraine. 2010. № 4 (17). С. 34-39.

3. Вишеславський Г. Що до вподоби: сучасне мистецтво, актуальне мистецтво, Modern art, contemporary art? Образотворче мистеитво. 2015. № 1. С. 86-87.

4. Гройс Б. Политика поэтики : сборник статей. М. : ООО «Ад Маргнем Пресс», 2012. 400 c. URL: https://imwerden. de/pdf/groys_politika_poetiki_2012_ocr.pdf.

5. Злобіна Т. Контемпораріарт чи актуальне мистецтво. Спільне. 2010. 8 червня. URL: https://commons.com.ua/uk/ kontemporariart-ta-aktualne-mistets/.

6. Маценко Н. «Все сучасне мистецтво - лайно»? Главком. 2018. 10 листопада. URL: https:/glavcom.ua/specprojects/ kult_front/vse-suchasne-mistectvo-layno-mistectvoznavec-nataliya-macenko-rozvinchuje-mifi-542852.html.

7. Радинський О. Контемпораріарт чи актуальне мистецтво. Спільне. 2010. 8 червня. URL: https://commons.com. ua/uk/kontemporariart-ta-aktualne-mistets/.

8. Сидор-Гібелінда О. Українці на Венеційській бієнале: сто років присутності. Київ : Інформаційно-аналітична агенція «Наш час», 2008. С. 302.

9. Сідлін М. Актуальне мистецтво: проблема перекладу та інтерпретація популярного терміну російської арткритики 90-х років. Візуальне мистецтво 80-90-х в контексті культурної ситуаиії XX ст. : матеріали міжнародної конференції (м. Київ, 23-25 листопада, 1999 рік). Київ, 1999. С. 65-67.

10. Скрипник-Миська. «Сучасне мистецтво», «сучасний художник»: трансформація понять. Ідеї, смисли, інтерпретаиії образотворчого мистецтва. Украӥнська теоретична думка ХХ століття: антологія. Львів : «Простір M», 2019. C. 274-281.

11. Смирная Л., Хаматов В., Пучков А. Модерное, современное и новейшее искусство. Сучасне мистецтво. К. : Акта, 2016. В. 12. С. 158-167.

12. Тейлор К. Ціна культурного ландшафту від Лесі Хоменко. Art Ukraine. 2010. № 2 (15). С. 71-75.

13. Шейнина М. Конец света? Terra incognita. 2000. № 9. С. 53-57.

14. Contemporary-art. Art Term. Tate. URL: https://www.tate.org.uk/art/art-terms/c/contemporary-art.

15. Contemporary-art in Context. Getting Started: an Introduction to Teaching with Contemporary Art. Art 21. 2016. URL: https://art21.org/for-educators/tools-for-teaching/getting-started-an-introduction-to-teaching-with-contemporary-art/ contemporary-art-in-context/.

16. Danto A. The Artworld. The Journal of Philosophy. 1964. V. 61, № 19. C. 571-584. URL: https://is.muni.cz/el/1421/ jaro2014/IM088/Danto____.pdf.

17. Richman-Abdou K. What is Contemporary Art? An In-Depth Look at the Modern-Day Movement. My Modern Met. 2019. August 11. URL: https://mymodernmet.com/what-is-contemporary-art-definition/.

\section{REFERENCES}

1. Avramenko O. Zminy paradyhmy funktsionuvannya obrazotvorchoho mystetstva v Ukraiini 1950-h-2005-ho rokiv. [Changes in the paradigm of fine arts functioning in Ukraine in the 1950s-2005s]. Essays on the history of the fine arts of Ukraine in the twentieth century. K. : Intertekhnologiia, 2006. Book. 2. P. 193-240 [in Ukrainian].

2. Vaibel P. My zhyvemo za chasiv, dlia yakykh kharakterna kryza kompetentnosti. [We live in the time characterized by a crisis of competence]. Art Ukraine. 2010. № 4 (17). P. 34-39 [in Ukrainian].

3. Vysheslavskyi G. Shcho do vpodoby: suchasne mystetstvo, aktualne mystetstvo, Modern art, contemporary art? [What do you like: nowaday art, relevant art, Modern art, contemporary art?] Obrazotvorche mystetsvo. 2015. № 1. P. 86-87 [in Ukrainian].

4. Grois B. Polytyka poetyky : sbornyk statei. [Politics of poetics : collection of articles]. M. : OOO "Ad Marhnem Press", 2012. 400 p. URL: https://imwerden.de/pdf/groys_politika_poetiki_2012_ocr.pdf [in Russian].

5. Zlobina T. Kontemporariart chy aktualne mystetsvo. [Contemporary art or currently emerging art]. Spilne. 2010. 8 June. URL: https://commons.com.ua/uk/kontemporariart-ta-aktualne-mistets/ [in Ukrainian].

6. Matsenko N. "Vse suchasne mystetstvo - laino?" [“All contemporary art is shit?"]. Glavkom. 2018. 10 November. URL: https:/glavcom.ua/specprojects/kult_front/vse-suchasne-mistectvo-layno-mistectvoznavec-nataliya-macenko-rozvinchuje-mifi-542852.html [in Ukrainian].

7. Radynskyi O. Kontemporariart chy aktualne mystetstvo. [Contemporary art or currently emerging art]. Spilne. 2010. 8 June. URL: https://commons.com.ua/uk/kontemporariart-ta-aktualne-mistets/ [in Ukrainian].

8. Sydor-Hibelinda O. Ukraiintsi na Venetsiiskii biienale: sto rokiv prysutnosti. [Ukrainians at the Venice Biennale: one hundred years of presence]. Kyiv : "Nash Chas" Information and Analytical Agency, 2008. 302 p. [in Ukrainian].

9. Sidlin M. Aktualne mystetstvo: problema perekladu ta interpretatsiia populiarnoho termina rosiiskoii art-krytyky 90-h rokiv. [Currently relevant art: the problem of translation and interpretation of the Russian art criticism popular term of the 90s]. Visual art of the 80-90s in the context of the cultural situation of the twentieth century: materials of the international conference (Kyiv, 23-25 November, 1999). Kyiv, 1999. P. 65-67 [in Ukrainian].

10. Skrypnyk-Myska. "Suchasne mystetstvo", "suchasnyi khudozhnyk": transformatsiia poniat. ["Contemporary art", "contemporary artist": the transformation of concepts]. Ideas, meanings, interpretations of the fine arts. Ukrainska teoretychna dumka XX stolittia: antologiia. [Ukrainian theoretical thought of the twentieth century: anthology]. Lviv : "Prostir - M", 2019. P. 274-281 [in Ukrainian]. 
11. Smyrnaia L., Khamatov V., Puchkov A. Modernoe, sovremennoe i noveishee yskusstvo. [Modern, contemporary and currently emerging art]. Suchasne mystetstvo. K. : Akta, 2016. V. 12. P. 158-167 [in Russian].

12. Tailor K. Tsina kulturnoho landshaftu vid Lesi Khomenko. [The price of the cultural landscape from Lesia Khomenko]. Art Ukraine. 2010. № 2 (15). P. 71-75 [in Ukrainian].

13. Sheinyna M. Konets sveta? [The end of the world?] Terra incognita. 2000. № 9. P. 53-57 [in Russian].

14. Contemporary-art. Art Term. Tate. URL: https://www.tate.org.uk/art/art-terms/c/contemporary-art [in English].

15. Contemporary-art. Getting Started: An Introduction to Teaching with Contemporary Art. Art 21. 2016. URL: https://art21.org/for-educators/tools-for-teaching/getting-started-an-introduction-to-teaching-with-contemporary-art/ contemporary-art-in-context/ [in English].

16. Danto A. The Artworld. The Journal of Philosophy. 1964. V. 61. № 19. P. 571-584. URL: https://is.muni.cz/el/1421/ jaro2014/IM088/Danto____.pdf [in English].

17. Richman-Abdou K. What is Contemporary Art? An In-Depth Look at the Modern-Day Movement. My Modern Met. 2019. August 11. URL: https://mymodernmet.com/what-is-contemporary-art-definition/ [in English]. 